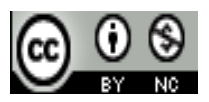

Jurnal Pendidikan IPS Indonesia is licensed under

A Creative Commons Attribution-Non Commercial 4.0 International License

\title{
TingKat Pengetahuan SiSWa Kelas X SMK MUhamMadiYAH 02 Wedi KABUPATEN KLATEN DALAM MITIGASI BENCANA GEMPAUBUMI
}

\author{
Dian Aditya Oktaviantika \\ Universitas Muhammadiyah Surakarta, Surakarta, Indonesia \\ E-mail: dianokta1992@gmail.com
}

\begin{abstract}
Tujuan penelitian ini adalah untuk mengetahui tingkat pengetahuan siswa kelas X SMK Muhammadiyah 02 Wedi dalam mitigasi bencana gempa bumi yang dilakukan oleh siswa kelas X di SMK Muhammadiyah 02 Wedi Kabupaten Klaten. Populasi kelas X di SMK Muhammadiyah 02 Wedi adalah 105 siswa dan jumlah sampel yang diambil dalam penelitian ini adalah 78 siswa dengan taraf kesalahan 10\% (Sugiyono, 2010. Penelitian ini merupakan jenis penelitian deskriptif kuantitatif dengan menggunakan perhitungan presentase. Pengambilan sampel yang digunakan adalah Simple Random Sampling, yaitu teknik pengambilan sampel secara undian (acak). Teknik pengambilan sampel untuk mengetahui mitigasi non struktural dalam menghadapi bencana gempa bumi yang dilakukan oleh siswa kelas X SMK Muhammadiyah 02 Wedi adalah Snowball Sampling. Jumlah sampel untuk mengetahui mitigasi non struktural dalam menghadapi bencana gempa bumi yang dilakukan oleh siswa kelas X SMK Muhammadiyah 02 Wedi adalah 9 siswa. Pengumpulan data dalam penelitian ini menggunakan angket dan wawancara.

Hasil penelitian menunjukan bahwa tingkat pengetahuan siswa kelas X baik kelas X.A, X.B maupun kelas X.C menunjukan tingkat pengetahuan cukup dalam mitigasi bencana gempa bumi sedangkan hasil penelitian menunjukan bahwa mitigasi non struktural yang dilakukan di sekolah SMK Muhammadiyah 02 Wedi dilakukan oleh orang lain bukan siswa akan tetapi siswa sudah mengetahui tujuan dilakukannya mitigasi non struktural di sekolah.
\end{abstract}

Kata Kunci: Bencana Gempa Bumi, Pengetahuan, Mitigasi.

\section{Pendahuluan}

Klaten merupakan Kabupaten yang berbatasan langsung dengan Kota Jogjakarta dan berada pada jalur patahan sehingga rawan sekali dengan bencana gempa bumi. Kabupaten Klaten terletak diantara $110^{\circ} 26^{\prime} 14^{\prime \prime} \mathrm{BT}$ - $110^{\circ} 47^{\prime} 51^{\prime \prime B T}$ dan 7³2'19"LS - 748'33"LS. Klaten memiliki ketinggian antara $100-400 \mathrm{~m}$ diatas permukaan laut (Klaten dalam Angka, 2002), dimana Kabupaten Klaten ini merupakan kabupaten yang mempunyai indeks kerawanan bencana gempa bumi yang menempati rangking ke-12 (BNPB, 2011).

Gempa bumi yang terjadi di Jogjakarta pada Tanggal 27 Mei 2006 tersebut berkekuatan 5,9 Skala Richter ( sumber: http: //dibi. bnpb. go. Id /DesInventar /results. jsp), sehingga seluruh wilayah disekitar Jogjakarta ikut merasakan getaran yang diakibatkan oleh gempa tersebut. Penyebabnya yaitu adanya dinamika aktifitas pergerakan kulit bumi berupa pergerakan lempeng Australia yang menumbuk lempeng Eurasia dimana sepanjang jalur Klaten sampai Jogjakarta merupakan daerah yang mempunyai patahan dan cekungan sehingga di Jogjakarta mudah mengalami bencana gempa bumi.

Dampak di Kabupatan Klaten yang diakibatkan oleh gempa bumi yang terjadi di Jogjakarata pada tanggal 27 Mei 2006 antara lain korban meninggal 1.045 orang, luka-luka 18. 127 orang, mengungsi 713. 788, rumah rusak berat 32 . 277, rumah rusak ringan 63. 615, fasilitas pendidikan 298, dan fasilitas kesehatan 111 (sumber://dibi.bnpb.go.Id/DesInventar/simple_res ults.jsp). Kecamatan Jogonalan merupakan salah satu Kecamatan yang terkena dampak dari gempa bumi di Jogjakarta pada Tanggal 27 Mei 2006. 
SMK Muhammadiyah 02 Wedi merupakan salah satu sekolah yang berada di Kabupaten Klaten, dimana sekolah tersebut terkena dampak langsung dari gempa bumi. Adapun dampak yang dirasakan di SMK Muhammadiyah 02 Wedi yang ditimbulkan dari gempa bumi tersebut adalah rusaknya infrastruktur sarana dan prasarana yang meliputi ruang kantor guru dan karyawan, tembok atau pagar dan ruang kelas retak-retak, serta terdapat 10 siswa korban luka-luka, karena pada saat terjadi gempa siswa tersebut hanya berlarian keluar tanpa arah dan tanpa adanya prosedur penyelamatan yang baik (Sumber: Wakasek Sekolah SMK Muhammadiyah 02 Wedi). Hal itu maka menjadi penting untuk dilakukannya penelitian mengenai pengetahuan siswa dan bagaimana mitigasi non struktutral siswa terutama siswa kelas $\mathrm{X}$ dalam menghadapi bencana gempa terutama pada saat terjadi bencana di sekolah.

Hasil orientasi dapat diketahuai bahwa kurangnya kegiatan sosialisasi pada siswa tentang mitigasi bencana gempa bumi di SMK Muhammadiyah 02 Wedi dan juga belum terintegrasikannya matapelajaran dengan materi mitigasi bencana yang diterapkan di sekolah, sehingga siswa minim akan pengetahuan tentang mitigasi bencana terutama bencana gempa bumi (Sumber: Bpk. Muhammad Arif Hidayat Kepala Sekolah SMK Muhamamdiyah 02 Wedi).

Berdasarkan latarbelakang di atas, maka penulis akan melakukan penelitian terhadap masalah tersebut dengan mengambil judul TINGKAT PENGETAHUAN SISWA KELAS $X$ SMK MUHAMMADIYAH 02 WEDI KABUPATEN KLATEN DALAM MITIGASI BENCANA GEMPA BUMI.

\section{Metode}

Penelitian ini bersifat menggunakan metode deskriptif kuantitatif. Cara memperoleh data penelitian ini menggunakan observasi, kuisioner, dokumentasi.

Populasi menurut Sugiyono (2010: 61), merupakan wilayah generalisasi yang terdiri atas obyek/subyek yang mempunyai kualitas dan karakteristik tertentu yang ditetapkan oleh peneliti untuk dipelajari dan kemudian ditarik kesimpulannya. Populasi yang digunakan pada penelitian ini adalah semua siswa kelas X SMK Muhammadiyah 02 Wedi Kabupaten Klaten yang berjumlah 105 siswa.

Penelitian ini menggunakan variabel tingkat pengetahuan siswa dalam mitigasi bencana gempa bumi menurut Widodo Pawirodikromo dalam buku Seismologi Teknik Rekayasa Kegempaan (2012) dan menggunakan variabel menurut Rayadi, Adi Tisna, Ayu Krisna, Yuliawati, Gama Putranto. In In Wahdiny, Rovy Roland, Susan Noveli, dalam buku Program Kesiapan Sekolah Terhadap Bahaya Gempa. 2012 untuk tindakan pengamanan dalam kelas dan di lingkungan sekolah siap gempa untuk mitgigasi non struktural yang dilakukan oleh siswa dan sebagai pedoman observasi.

\section{KESIMPULAN}

Penelitian mengenai tingkat pengetahuan siswa kelas X SMK Muhammadiyah 02 Wedi Kabupaten Klaten dalam mitigasi bencana gempa bumi dapat ditarik kesimpulan sebagai berikut:

1. Tingkat pengetahuan siswa kelas $\mathrm{X}$ baik kelas X.A, X.B maupun X.C SMK Muhammadiyah 02 Wedi tentang mitigasi bencana gempa bumi berada pada kategori cukup.

2. Tindakan Mitigasi non struktural yang terdapat di SMK Muhammadiyah 02 Wedi dilakukan oleh orang lain bukan siswa, akan tetapi siswa sudah mengetahui tujuan dilakukannya tindakan mitigasi non struktural.

\section{REFERENCES}

Adi Tisna, Rayadi, Ayu Krishna, Yuliawati, Gama Putranto, In In Wahdiny, Rovy Roland, Susan Novelia. 2002. Program Kesiapan Sekolah Terhadap Bahaya Gempa. Bandung: ITB

Anonim, 2002. Klaten Dalam Angka 2002/2002. Klaten: Badan Pusat Statistik Kabupaten Klaten dan Bapeda Kabupaten Klaten.

Cristanto, Joko. 2011. Gempa Bumi, Kerusakan Lingkungan, Kebijakan dan Strategi Pengelolaan. Yogjakarta: Liberty Yogjakarta.

Kurniawan, Lilik, Ridwan Yunus, Mohd Robi Amri. Narwawi Pramurdiarta. 2011. Indeks Rawan Bencana Indonesia. Jakarta: BNPB. 
Pawirodikromo, Widodo. 2012. Seismologi Teknik Rekayasa Kegempaan. Yogyakarta: Pusaka Pelajar.

Pribadi, Krisna S. Engkon K. Kertapati. Diah Kusumastuti. Hamzah Latief. Hendra Grandis, Eng. Imam A. Sadisun, Soebagiyo Soekarnen. Harman Ajiwibowo. Retno Dwi. Ayu Krishna Juliawati. Farah Mulyasari. Novya Ekawati. Bayu Novianto. 2008. Pendidikan Mitigasi Bencana. Bandung: ITB.

Sugiyono. 2010. Statistika Untuk Penelitian. Bandung: Alfabeta.

Marsudi, Saring, Rubino Robiyanto, Sri Hartini. 2008. Perkembangan Perserta Didik. Surakarta: FKIP Universeitas Muhammadiyah Surakarta.

Mudyahardjo, Redja. 2001. Pengantar Pendidikan Sebuah Studi Awal Tentang Dsar-dasar Pendidikan pada Umumnya dan Pendidikan di Indonesia. Jakarta: PT RajaGrafindo Persada

Wida, Adhi Perdhana. 2013. "Pengetahuan Mitigasi Non Struktural Bencana Gempa Bumi Siswa Smp Muhammadiyah 8 Wedi Di Kecamatan Jogonalan Kabupaten Klaten".SKRIPSI,Fakultas Keguruan dan Ilmu Pendidikan, Universitas Muhammadiyah Surakarta.

www.dibi.bnpb.com, diakses pada tanggal 12

Oktober 2013. 